\title{
EDUCATION ON WORLD REFERENCE BASE FOR SOIL RESOURCES (WRB) - EXAMPLE OF GOOD PRACTICE
}

\author{
Alina OMANOVIĆ ${ }^{*}$
}

\begin{abstract}
The World Reference Base for Soil Resources (WRB) research work started back in 1980. under the program named International Reference Base for Soil Classification (IRB). World Reference Base for Soil Resources was established in 1998., and its design provide easier communication between scientists to whom soil systematic is primary area of research. International Field Course of the World Reference Base for Soil Resources, held in Gödöllö, Hungary, from 01st to 05th of September, 2015.was organized to celebrate the International Soil Year. Soil Judging Contest of WRB was organized during the course. Students from Bosnia and Herzegovina, primarily students of Faculty of Agricultural and Food Sciences, University of Sarajevo and Faculty of Agriculture, University of Banja Luka attended the course. The above mentioned course and the contest were unique opportunity for students, young scientists and experts as well as those who have been already involved or interested in identification and characterization of the basic soil types all around the world to share information and experience. The unique field study program provided an opportunity to participants to gain new knowledge on Anthrosols, Calcisols, Chernozems, Kastanozems, Phaeozems, Gleysols, Luvisols, Solonetz and Vertisols in accordance to the World Reference Base for Soil Resource. Importance of the continuation of good practices and implementation of this type of field learning about WRB classification is crucial not only at the global level, but also at the regional one. This paper aims to stress the importance of education about WRB classification in order to improve and adapt the national classification system, importance of applied soil science in society in general and to increase the communication with other related disciplines globally.
\end{abstract}

\section{INTRODUCTION}

Soil is defined as the 3-dimensional top layer of the earth's crust. It is formed by the organic matter, mineral particles, water, air and living organisms. Soil has the properties that reflect the impact of the vegetation, fauna, climate, man and topography on the

\footnotetext{
1* Faculty of Agricultural and Food Sciences, University of Sarajevo, Zmaja od Bosne 8, 71000 Sarajevo, Bosnia and Herzegovina, alina.omanovic@gmail.com
} 
soil's parental material over a variable time span. It is in fact a complex, variable and living medium, where each of the five soil forming factors varies in time and space. A soil formation or pedogenesis is an extremely slow process and soils are still changing where it is shown in their soil profile.

Opposed to the taxonomy in the biology, which identify and separate all organisms and give it taxonomic rank, the world's soil cover is a continuum. In the early days of soil science, soil classification was based on the genesis of the soil. It is interesting that even after more than hundred years of modern soil science, since recently there was not developed and accepted unique system for the classification of the soils. Many soil classification where developed over the years which reflect different views held on concepts of soil formation and minor differences of opinion about criteria to be used in the classification. Today it can be said that The World Reference Base for Soil Resources (WRB), which was established in the 1998., is thankful for the great effort of the development and classification of the soils in the world on the and also creating and refining a common and global language for the soil classification. The great number of countries accepted this classification and many national classifications correlate with WRB (Deckers et al.).

The World Reference Base (WRB) is based on the Legend (FAO-Unesco, 1974) and the Revised Legend (FAO, 1988) of the Soil Map of the World (FAO-Unesco, 1971-1981). In 1980, the International Society of Soil Science (ISSS, since 2002 the International Union of Soil Sciences, IUSS) formed a Working Group 'International Reference Base for Soil Classification' for further elaboration of a science based international soil classification system. This Working Group was renamed 'World Reference Base for Soil Resources' in 1992. The Working Group presented the first edition of the WRB in 1998 (FAO, 1998) and the second edition in 2006 (IUSS Working Group WRB, 2006). In 1998, the ISSS Council endorsed the WRB as its officially recommended terminology to name and classifies soils (IUSS Working Group WRB, 2015).

To celebrate the International Year of Soils (IYS), an International Field Course and Soil Judging Contest was organized from $01^{\text {st }}$ to $05^{\text {th }}$ September 2015 in Gödöllö, Hungary. This occasion was the great opportunity for students, researchers and people interested in the soil classification from around the world to interact and experience the nature, landscapes and soils of the Danube Basin and Hungary.

International Field Course and Soil Judging Contest was organized by the Hungarian Soil Science Society (HSSS), SzentIstvan University (SZIU), International Union of Soil Sciences (IUSS), European Commission - Joint Research Centre (JRC), Institute for Soil Sciences and Agricultural Chemistry, Centre for Agricultural Research, Hungarian Academy of Sciences (HAS - RISSAC), University of Miskolc (UNIMIS) and professor Erika Micheli (HSSS, SZIU) as the chair of organizing committee.

International Field Course and Soil Judging Contest was opportunity for the participants to learn more and to use their previous knowledge and practical skills to describe, 
understand and interpret soil characteristics in the field. Participants where describing a series of profiles using basic filed tools, selected standards and guidelines and expand their ability to correctly describe each soil, evaluate potential soil functions and interpret their capacity to perform under different land use and management practices.

Under the sponsorship of JRC, students from Bosnia and Herzegovina (BiH), primarily students of Faculty of Agricultural and Food Sciences, University of Sarajevo and Faculty of Agriculture, University of Banja Luka had opportunity to attend the course. Students from $\mathrm{BiH}$ where in one team named "Team of $\mathrm{BiH}$ " where the coaches were Dr. Arwyn Jones and Dr. Endre Dobos.

\section{RESULTS}

For the International Field Course and Soil Judging Contest participants registered and came from all continents, 28 countries (Afghanistan, Albania, Armenia, Australia, Bosnia and Herzegovina, Brazil, Croatia, Germany, Hungary, Japan, Kenya, Kosovo, Laos, Montenegro, Nigeria, Philippines, Rwanda, Serbia, South Africa, South-Korea, Spain, Sudan, Tajikistan, Tunisia, Turkey, Uganda, United Kingdom, USA). Including the instructors and local supervisors, 120 people participated in the event.

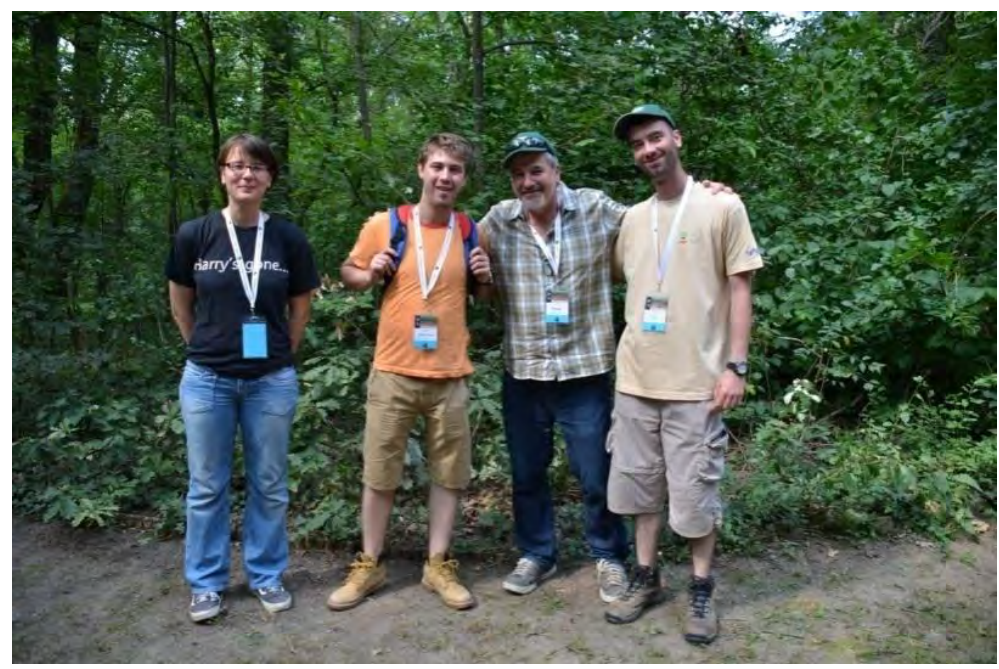

Figure 1. Team of $\mathrm{BiH}$ with their coach Arwyn Jones

The course was consisted from theoretical and field practical part. For the theoretical part the team of international soil experts gave an overview of the site and pointed out about soil functions, profile description and soil classification standards. Later on, local experts introduced the landscape and soil condition of Hungary. 
For the field session each team had necessary equipment for field that consist of:

- $\quad 10 \% \mathrm{HCl}$ dropper bottle

- Soil knife/digging tool

- Hand lens

- Water bottle

- Container for soil samples

- Clinometer

- Clipboard

- Plastic bags (for collection of standard soil samples for texture determination)

- Calculator

- Munsell Soil Color Chart books

Each team receive an official handbook and World Reference Base for Soil Resources (IUSS Working Group WRB, 2014) that was kindly provided by the organizers.

For the pits there were certain rules that need be followed and typical section was selected and clearly designated as the control section by the organization officials. The control section was used for measurements of horizon depths and boundaries and had to remain undisturbed and unblocked. A measuring tape was placed in the each control section at all pits. Up to seven horizons where described within given depth. At each site, a card was given the profile depth to be considered, the number horizons to be described and chemical or/and physical data that may be required for classification.

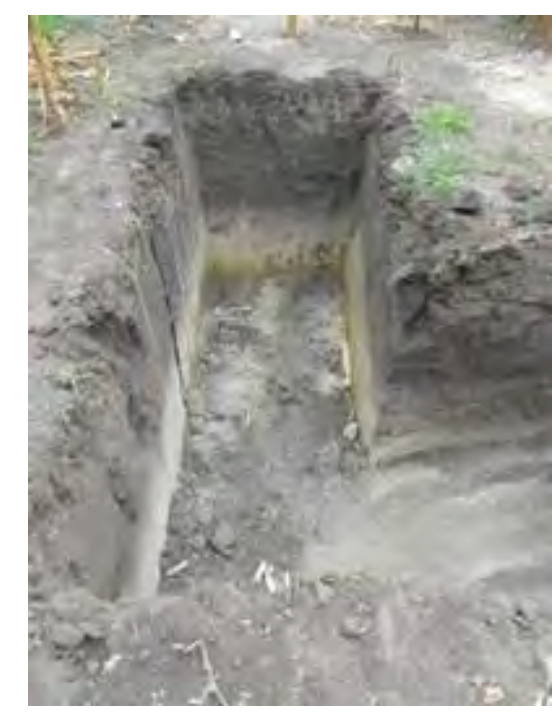

Figure 2. Pit with the control section 
Every participant got one scoresheet/team. Following the instructions of the coaches, considering the information on the card and instruction of the handbook the scoresheets were filled.

SCORESHEET

I use WRB $\square \quad$ Soil Taxonomy $\square$

International Field Course and Soil Judging Contest

Site number ___ Contestants ID ___ Describe

Describe __ horizons within a depth of

$\mathrm{cm}$

I. SITE CHARACTERISTICS

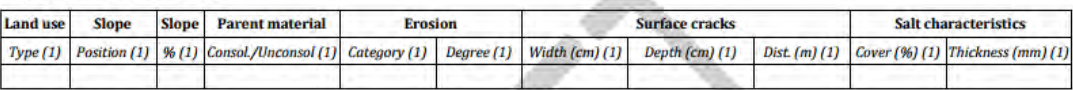

II. SOIL DESCRIPTION

\begin{tabular}{|c|c|c|c|c|c|c|c|c|c|c|c|c|c|c|c|c|c|}
\hline \multicolumn{3}{|c|}{ Horizon } & \multicolumn{3}{|c|}{ Boundary } & \multicolumn{3}{c|}{ Soil color } & \multicolumn{2}{c|}{ Carbonates } & \multicolumn{3}{c|}{ Texture } & \multicolumn{2}{c|}{ Structure } & Redox feat. & Coatings \\
\hline \multicolumn{2}{|c|}{\begin{tabular}{c} 
Master \\
\hline $\begin{array}{c}\text { Prefix } \\
(1)\end{array}$
\end{tabular}} \\
\hline
\end{tabular}

III. SOIL PROFILE CHARACTERISTICS

IV. INTERPRETATIONS

\begin{tabular}{|c|c|c|c|c|c|c|c|c|}
\hline \multicolumn{2}{|c|}{$\begin{array}{c}\text { Hydraulic } \\
\text { conductivity (3) }\end{array}$} & \multirow{2}{*}{\begin{tabular}{l|l}
\multicolumn{2}{c}{ Effective soil depth (3) } \\
& Very deep $(>150 \mathrm{~cm})$
\end{tabular}} & $\begin{array}{c}\text { Type of the restrictive } \\
\text { layer(s) (3) }\end{array}$ & AWHC (3) & Soil Wetness (3) & \multirow{2}{*}{\begin{tabular}{|c|c|}
\multicolumn{1}{|c|}{$\begin{array}{c}\text { Potato } \\
\text { Production (3) }\end{array}$} \\
& $\begin{array}{l}\text { Class 1 } \\
\text { Optimal }\end{array}$ \\
\end{tabular}} & \multirow{2}{*}{\begin{tabular}{|l|l|}
$\begin{array}{l}\text { Irrigated Corn } \\
\text { Production (3) }\end{array}$ \\
$\mid \begin{array}{l}\text { Class 1 } \\
\text { Optimal }\end{array}$ \\
\end{tabular}} & \multirow{2}{*}{\begin{tabular}{|c|c|}
$\begin{array}{c}\text { Local Roads for } \\
\text { Comm. Planning (3) }\end{array}$ \\
& $\begin{array}{l}\text { Class 1 } \\
\text { Optimal }\end{array}$ \\
\end{tabular}} \\
\hline Surface & Limiting & & \begin{tabular}{|l|} 
Bedrock \\
\end{tabular} & $\mathrm{VL}$ & Class 1 & & & \\
\hline $\mathrm{H}$ & $\mathrm{H}$ & Deep $(100-150 \mathrm{~cm})$ & $>25 \% \mathrm{CaCO}_{3}$ & $\mathrm{~L}$ & Class 2 & \begin{tabular}{|l|} 
Class 2 \\
Suitable
\end{tabular} & \begin{tabular}{|l|} 
Class 2 \\
Suitable \\
\end{tabular} & \begin{tabular}{|l|} 
Class 2 \\
Suitable
\end{tabular} \\
\hline M & M & Mod. deep $(50-99 \mathrm{~cm})$ & Natric horizon & Mo & Class 3 & \begin{tabular}{|l|} 
Class 3 \\
Unsuitable \\
\end{tabular} & \begin{tabular}{|l}
$\begin{array}{l}\text { Class } 3 \\
\text { Unsuitable }\end{array}$ \\
\end{tabular} & \begin{tabular}{|l|}
$\begin{array}{l}\text { Class } 3 \\
\text { Unsuitable }\end{array}$ \\
\end{tabular} \\
\hline$L$ & L & Shallow $(20-49 \mathrm{~cm})$ & Salie horizon & $\mathrm{H}$ & Class 4 & & & \\
\hline & & Very shallow $(<20 \mathrm{~cm})$ & $\begin{array}{l}\text { SiC, C or SC, struc- } \\
\text { tureless + massive }\end{array}$ & & Class 5 & & & \\
\hline
\end{tabular}

V. DIAGNOSTICS AND SOIL CLASSIFICATION

\begin{tabular}{|c|c|c|c|c|}
\hline \multicolumn{5}{|c|}{ World Reference Base for Soil Resources (2014) } \\
\hline \multicolumn{3}{|c|}{ Diagnostics } & \multirow{2}{*}{$\begin{array}{l}\text { Reference Soil Group } \\
\text { (15) }\end{array}$} & \multirow{2}{*}{$\begin{array}{c}\text { Principal } \\
\text { qualifiers (5) }\end{array}$} \\
\hline Horizons (10) & Properties (5) & Materials (5) & & \\
\hline Argic & Abrupt textural difference & Albic materials & Anthrosols & Luvic \\
\hline Calcic & Gleyic properties & Colluvic material & Solonetz & Calcic \\
\hline Cambic & Lithic discontinuity & Fluvic material & Vertisols & Haplic \\
\hline Chernic & Protocalcic properties & & Solonchaks & Gleyic \\
\hline Histic & Reducing conditions & & Gleysols & Mollic \\
\hline Hortic & Shrink-swell cracks & & Chernozens & Stagnic \\
\hline Mollic & Stagnic color patterns & & Kastanozems & Vertic \\
\hline Natric & & & Phaeozems & Hortic \\
\hline Salic & & & Calcisols & \\
\hline Umbric & & & Luvisols & \\
\hline Vertic & & & Cambisols & \\
\hline & & & Arenosols & \\
\hline & & & Fluvisols & \\
\hline
\end{tabular}

\begin{tabular}{|c|c|c|c|c|c|}
\hline \multicolumn{6}{|c|}{ Soil Taxonomy (12 ${ }^{\text {th }}$ Edition, 2014) } \\
\hline Epipedon (10) & Subsurface horizon (5) & Diagnostic characteristics (5) & Order (10) & Suborder (5) & Great group (5) \\
\hline Anthropic & Albic & Abrupt textural change & Vertisol & Ustic & Argi \\
\hline Mollic & Argillic & Identifiable Secondary carbonates & Ultisol & Aquic & Calci \\
\hline Ochric & Calcic & Lithologic discontinuity & Mollisol & Udic & Natr \\
\hline Umbric & Cambic & Slickensides & Alfisol & Psamm & Hapl \\
\hline & Natric & Aquic conditions & Inceptisol & & Usti \\
\hline & Salic & 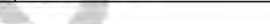 & Entisol & & \\
\hline
\end{tabular}

Figure 3. Draft of the score sheet 
As it can be seen on the Figure 3. these are the score sheets for the each pit that need to be filled. Scoresheet was divided into five parts, as follows:

I. Soil characteristic, where it was observed land use, slope, parent material, erosion, surface cracks and salt characteristic.

II. Soil description which contains horizon, boundary, soil colour, carbonates, texture structure, redox features and coatings

III. Soil profile characteristic where was hydraulic conductivity, effective soil depth, type of the restrictive layer(s), AWHC (Available Water-Holding Capacity) and soil wetness marked

IV. Interpretation for the suitability of potato production, irrigated corn production and local roads for community planning

V. Diagnostic and soil classification where it could be used 2 types of classification: WRB and Soil taxonomy.

\section{DISCUSSION}

International Field Course and Soil Judging Contest was a great opportunity to learn more about classification, field procedures and techniques. During the four day course young people could learn from the prominent soil scientist of the today about classification of Hungarian soils and Danube basin. But the thing that made this course even more demanding was the opportunity to test your knowledge of World Reference Base of Soil Resources on the last day. Many of the participants had not had the chance to go in to the pit and do one of the techniques and field procedures that was required for the WRB classification or they lacked the experience. But till the end all of them carried valuable field knowledge to their countries and it can be said that they understood and gain need experience.

This course is also an example of the good learning practice and implementation of this type of field learning about WRB classification. Even though many of the contestants of this course were not experience in the WRB classification, not only in their country where they use national classification but also with the soils of Hungary, local team of experts introduced it and made an effort to all participants to understand pedogenesis and to distinguished between all different types of soils in Hungary and Danube basin. Because of that this method of learning is the best practice of teaching WRB.

After this course it can be said that WRB is complete classification system that gives accommodation to national soil classification systems. Also what was learned during this course is that WRB cannot be substitute for national soil classification systems, but to serve as a common ground for the communication on the international level. Also to add WRB can serve as a bridge between existing national classifications and to serve as communication tool for gathering soil databases for the monitoring of the world's soil 
resource. As it is known with strong database the biggest problem of today in the soil science would be easier to tackle.

This type of event has a goal to integrate students, teachers from Soil science area through challenging and dynamic activities outside the classroom. It is really important that faculties and universities apply this approach of learning Pedology because it interactive and valuable skills in professional life. Because of all of this is important to the continuation of good practices and implementation of this type of field learning about WRB classification. With this course young people, next soil scientist are educated and introduced into classification of soils on the global level. It is crucial to have this even not only at the global level, but also at the regional or national level where young soil scientist would gain skills to describe and classify soils and this experience and knowledge will be carried into the workplace, from agriculture to industry.

\section{CONCLUSIONS}

Translation of the WRB classification can be easily introduced to any language in the world, the nomenclature is defined precisely and some of the terms are retained from the traditional nomenclature. So it is important to educate about WRB classification in order to improve and adapt the national classification system according to WRB and update it with current changes of the soil science. $\mathrm{BiH}$ is using national classification system that is adapted from Yugoslavian national classification system. The need to correlate $\mathrm{BiH}$ classification system with WRB is expressible special now when $\mathrm{BiH}$ have tendency to join European Union. All the ministries and scientist that are responsible for this matter will need as soon as possible to start with field and laboratory soil investigations, as specified by criteria and normative given by WRB. International Field Course and Soil Judging Contest it giving the opportunity for young scientist from $\mathrm{BiH}$ to learn WRB from international expert and in the future to apply their gain knowledge in correlation of national systems with WRB. In that sense not only to have better communication with soil scientist around the world, then also to help to improve and bring up to date soil science in $\mathrm{BiH}$.

\section{REFERENCES}

Deckers Jozef et al., World Reference Base for Soil Resources - in a nutshell, European Soil Bureau- Research Report No. 7.

FAO. 2006. Guidelines for Soil Description. Food and Agriculture Organization of the United Nations, Rome.

International Field Course and Soil Judging Contest, http://soiljudging-iys2015.com/, Accessed: November. 2015.

IUSS Working Group. 2014. World Reference Base for Soil Resources. World Soil Resources Report 106. Food and Agriculture Organization of the United Nations, Rome. 
Official Handbook of the International Field Course and Soil Judging Contest, September $1-5,2015$, Gödöllö, Hungary.

Soil classification, http:/www.fao.org/soils-portal/soil-survey/soil-classification/en/, Accessed: October. 2015.

Subject: World Reference Base, http://www.fao.org/soils-portal/soil-survey/soilclassification/world-reference-base/en/, Accessed: October. 2015. 